\title{
福岡平野周辺で確認された広域テフラについで1)
}

\author{
下山 正一2) - 溝田 智 俊3) - 新井 房 夫 ${ }^{4)}$
}

\section{Affirmation of the Widespread Tephras in and around the Fukuoka Plain ${ }^{\text {) }}$}

\author{
Shoichi Shimoyama ${ }^{2)}$, Chitoshi Mizota ${ }^{3)}$ and Fusao ARAI ${ }^{4)}$
}

\section{I. は じめに}

北部九州に分布する古砂丘砂層には，土壎化した層準 に数枚の後期更新世テフラが含まれていることが知られ ている（成瀬・井上，1982）。成瀬・井上（1982）は, 北部九州地域の唐津市，玄海町および芦屋町に分布する 古砂丘を研究し, 古砂丘砂層がレスなどの風成塵と海浜 砂および風成砂からなることを明らかにした．風成塵の 多い層準は 5 枚ほどの古土壤の層として識別され，さ らにこれらにはしばしばテフラが認められる，福岡平野 を除く北部九州地域で従来識別されたテフラは，下から 唐津火山兏 (KT), 阿蘇 4 火砕流 (Aso-4pfl), 姶良 $\mathrm{Tn}$ 火山灰 (AT), それに古砂丘砂層と新砂丘砂層の間 に挾まれている鬼界アカホヤ火山死（K-Ah）の 4 種類 である。

筆者らは，玄界灘・響灘沿岸地域において，テフラの 調查を行い，成瀬・井上（1982）の報告にあるテフラを 再確認するとともに, Aso-4pfl を除いて, 従来テフラ の報告事例のなかった福岡平野周辺でも新たにテフラ層 を確認し，新たにこの地域で発見された埋没土中のテフ ラを検討した。 その結果，埋没土中のテフラは K-Ah 火山灰で，明瞭なテフラ層を形成していることが明らか になった。また，成瀬・井上（1982）の報告したテフラ のうち，肉眼でも明瞭に識別可能なテフラ層を形成する のは, KT と Aso-4pfl の 2 層のテフラだけで, AT と $\mathrm{K}-\mathrm{Ah}$ は土壤中に分散し, 土壤物質中に拡散・混交して いることがわかった。これに加えて，成瀬・井上 （1982）の KT の正体は, 町田・新井（1983a）の指摘 したAtaに対比しうることをつきとめた。一方，土袞
学的検討により，福岡における $\mathrm{K}-\mathrm{Ah}$ 産出層準の土壤 学的産状は, 南部㧍よび東部九州での産状とは若干異な っていることも判明した.

北部九州の旧石器時代・縄文時代についての研究で は,Aso-4pfl 以外のテフラはこれまでほとんど注目さ れてこなかった経緯がある。そそれは，多くの広域テフラ の供給源である南部九州と比べ，北部九州がそれらの分 布の風上に位置するとみなされてきたことによると思わ れる. 今回の発見および確認は，北部九州地域の第四紀 学の研究に新たな対比の手がかりを与えるものと考えら れる.

\section{II. 福岡付近の地質概略および広域テフラ}

Ata，Aso-4pfl，K-Ah は，岡坦町榎坂 (図 1, 図 2, Loc. 3）と福岡市東区奈多から雁の巣付近にかけての玄 界灘に面した海の中道の連続露頭 (図 1, 図 2, Loc. 1, 2）に打いて，それぞれ明瞭に識別できる。地層柱状図 を図 2 に，模式的な地質断面図を図 4 に示す。福岡平 野周辺の第四系の層序は, 下山（1989）によって表 1 のようにまとめられている. また，岡垣付近の第四系の 層序は藤井 (1986) が再調查している. 今回は福岡付 近，特に良好なテフラ層の露頭が見出された海の中道を 中心に，地質の概略を述べる.

現在みられる福岡平野の第四紀層の形成は, 少なくと も 2 サイクルの水河性海面変動現象と関係している. すなわち，海の中道砂層・箱崎砂層・博多湾シルト層・ 住吉層 - 桧原砂層 - 大坪砂砂層の各部層の形成期は, 最 終氷期以降の 1 サイクルに属している. また, 奈多砂 層 - 須玖火山灰層 - 須崎層 - 地行泥層 - 南面里砂層の各

1) 1988 年 8 月 2 日受付. 1989 年 6 月 10 日受理.

2) 九州大学理学部地質学教室 Department of Geology, Faculty of Science, Kyushu University.

3) 九州大学農学部農芸化学教室 Department of Agricultural Chemistry, Faculty of Agriculture, Kyushu University.

4) 群馬大学教育学部地学教室 Department of Geology, Faculty of Education, Gunma University. 


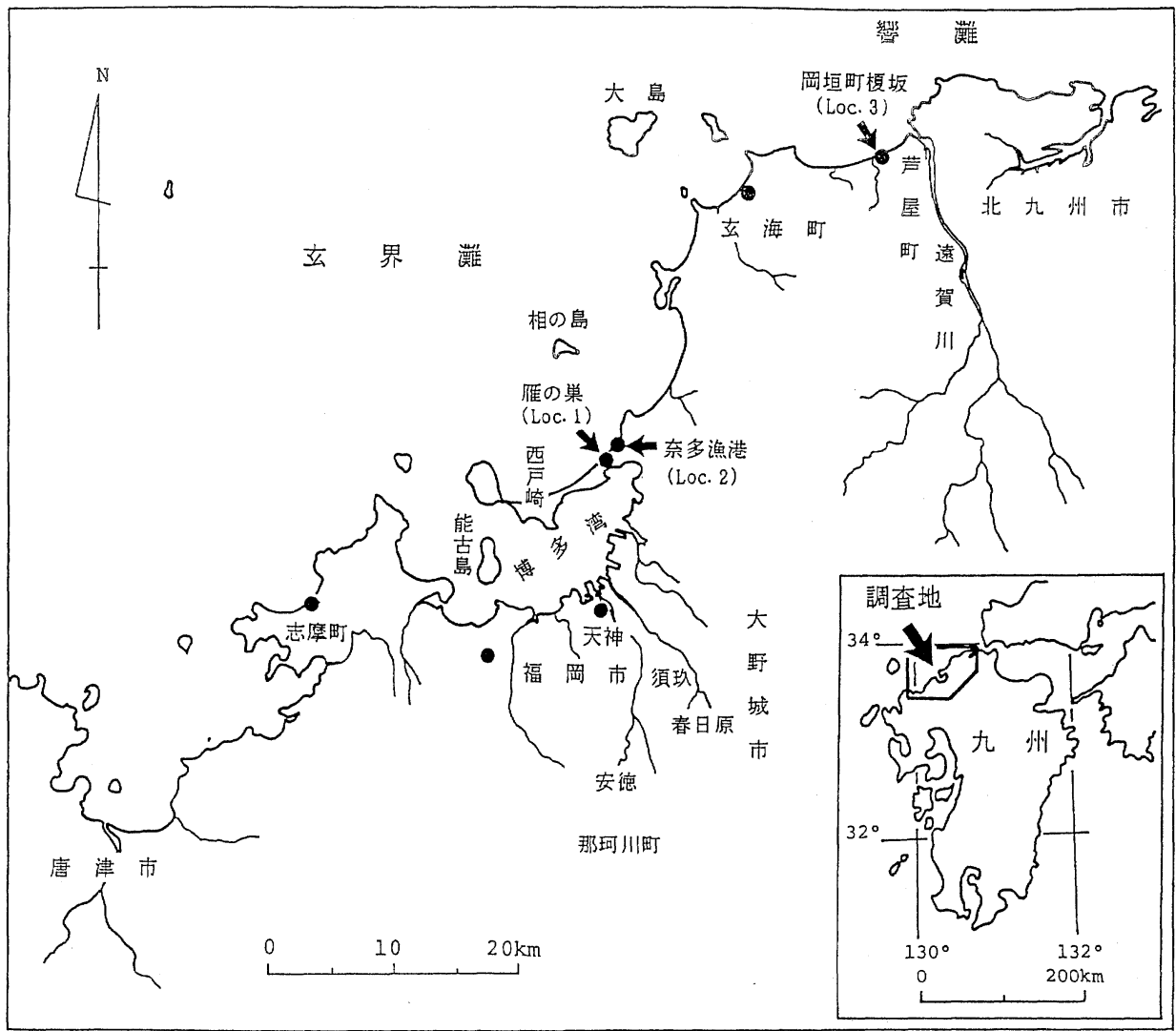

図 1 調査地域である福岡平野周辺の略図

黒丸は鬼界アカホヤ火山灰 ( $\mathrm{K}-\mathrm{Ah})$ が埋没性黒ボク土として確認された地点.

累層の形成期は，最終間水期とそれ以前の水期の 1 サ イクルの海退海進に属している.

福岡市東区㷳の巣から西戸崎にかけての海の中道は, 全長約 $10 \mathrm{~km}$, 最大幅 $1.25 \mathrm{~km}$ にわたる砂丘と砂州か ら構成され，その最高標高は奈多付近で $34 \mathrm{~m}$ である. また，同様の砂丘や砂州を構成する砂層は，博多湾を取 り巻くように分布している。このうち，博多湾北岸に分 布するものを「海の中道砂層」, 博多湾南岸に分布する ものを「箱崎砂層」と呼ぶ（下山，1989）.

海の中道砂層は，岡垣地域の三里松原砂丘層に対比さ れ，いわゆる “新砂丘砂層”に相当する，それは海浜砂 と風成砂部分からなるが，両者は汀線近くでは細かく錯 綜し，区別できない．本層の砂は，粒度の揃った中粒砂 ないし細粒砂を主体とした淡黄色の石英砂からなる．本 層の厚さは変化が激しいが，西戸崎付近では約 $15 \mathrm{~m}$ で ある，本層の基底面の標高は+5〜-11 m である，本層 は，シオヤ鼻で古第三紀層を，膺の巣から三苫にかけて
は古砂丘砂層（奈多砂層）を不整合に覆っている．

奈多砂層は，岡垣地域の芦屋・栗屋砂丘層に対比さ れ，いわゆる “古砂丘砂層”に相当する．三苫から雁の 巣にかけての海の中道北岸には, 奈多砂層の好露出が連 続している．奈多砂層の厚さは，場所によりまちまちで あるが, 奈多漁港付近では露頭の高さと試錐結果から約 $29 \mathrm{~m}$ と見積もられる，奈多砂層は，淡黄色の細粒ない し中粒砂層を主体としている。 それは褐色の古土壤部分 を挾んでおり，海の中道砂層とは明らかに区別できる. また，数回の上方細粒化の堆積サイクルが認められる. 各サイクルの細粒部分には風成塵を多く混入し，その最 上部は褐色または赤褐色の古土㙵部分が占める。こうし たサイクルは, 砂の供給量の変化に対応していると判断 されることから最も土壤化の進んだ部分を各サイクルの 上限として，本層を 5 つの堆積単位（部層）に細分し た。各部層を上から $\mathrm{A}$ 部層, $\mathrm{B}$ 部層, $\mathrm{C}$ 部層, $\mathrm{D}$ 部層 と呼ぶ(図 2, Loc. 1, 2). 


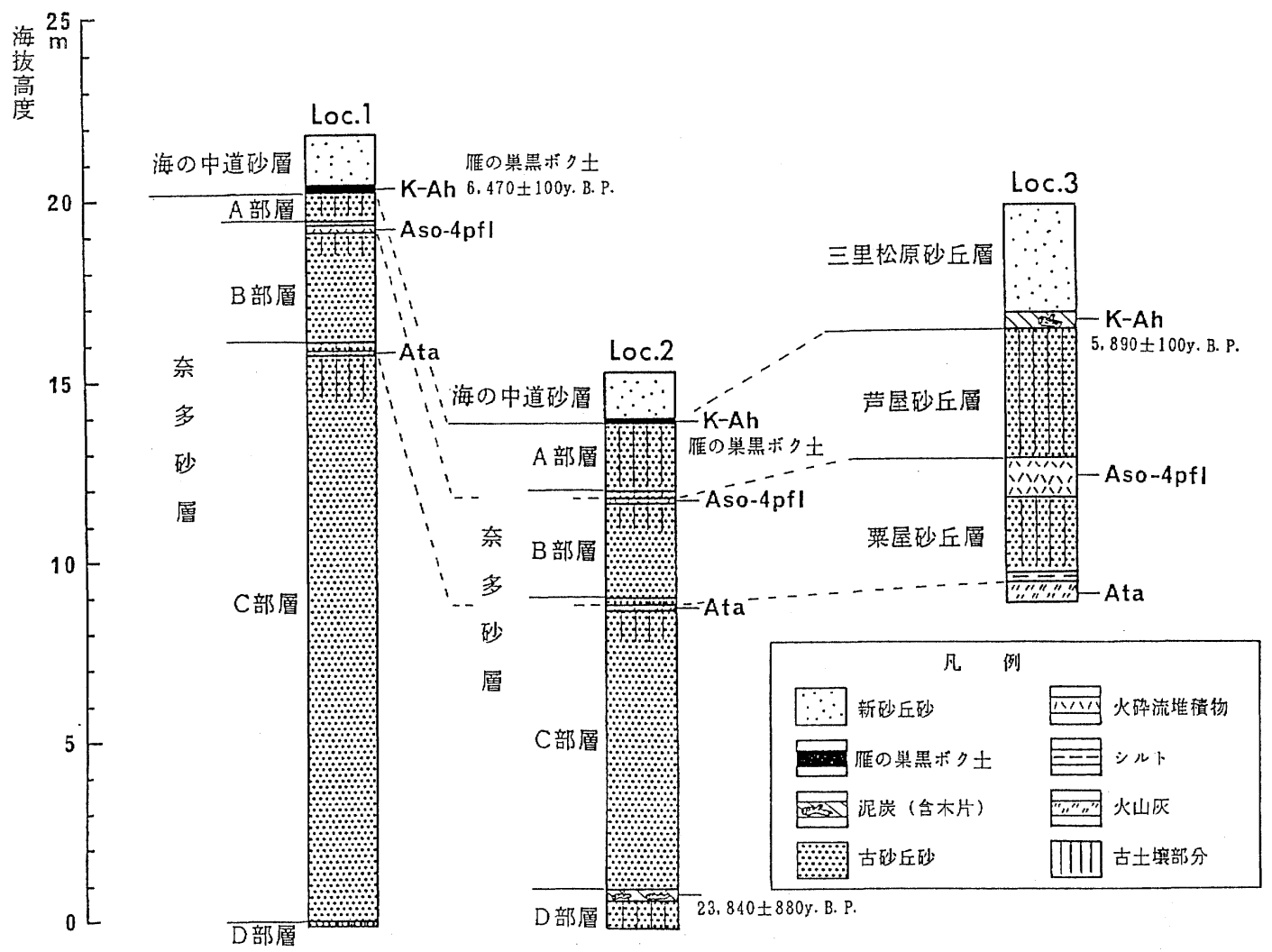

闵 2 福岡市東区奈多漁港（Loc. 1, 2） と岡垣町榎坂（Loc. 3）に扔ける古砂丘砂層の地質柱状図 数值は ${ }^{14} \mathrm{C}$ 年代值であり, 縦線の部分は古土壤を表す.

奈多漁港の改修工事の際に, D 部層の最上部に $15 \mathrm{~cm}$ ないし $20 \mathrm{~cm}$ の泥炭層が露出し, 横倒しになったおび ただしれ太状の埋もれ木がみつかっている（汹 2,

Loc. 2)。また, A 部層と $\mathrm{C}$ 部層の古土畩部分には, 明 瞭なテフラ層が認められる（㲸 2，Loc. 1，2）。

$\mathrm{A}$ 部層直上のテフラ層は埋没黒ボク土として見出さ れるが, 明らかに古砂丘砂層形成後, 新砂丘砂層形成前 の混入物であり，その厚さは雁の巣では約 $20 \mathrm{~cm}$ ない し $30 \mathrm{~cm}$ である. 他の 2 つのテフラ層は粘土化してお り，層序的にも古砂丘砂層形成期の混入物である.

\section{1. 雁の巣黒ボク土の土㙵学的性質}

$\mathrm{K}-\mathrm{Ah}$ は, 福岡平野周辺では埋没黒ボク土中に見出さ れる。ここでは，この埋没黒ボク土を便宜上，「雁の巣 黒ボク土」と呼ぶ. その模式地は, 福岡市東区奈多漁港 から雁の巣付近の立界灘に面した砂丘地帯である。难の 巣黒ボク土は, 風成砂と太陽光下でキラキラ光る火山ガ ラスを混えた，特徵ある樹脂状の黑色光沢を持つ細粒質 物質から構成されている。このきわめて特徵的な黒色の
原因が，火山灰の風化過程で生成されるアルミニウムー 腐植複合体に由来するのか，あるいは排水不良の条件下 で生成されるいわゆる黒泥状のものに由来するのかを確 認する目的で，大羽・本名（1984）の方法により，雁の 巣黒ボク土の腐植の分析を行い, 次の結果を得た.

$$
\begin{array}{r}
\Delta \log \mathrm{K}=0.497 \\
\mathrm{CD}=16.9
\end{array}
$$

ここで, $\Delta \log \mathrm{K}$ (色調係数) は $\log \mathrm{K}_{400}$ と $\log \mathrm{K}_{600}$ との 差（ $\mathbf{K}_{400}$ および $\mathbf{K}_{600}$ はそれぞれ抽出した腐植溶液の $400 \mathrm{~nm}$ と $600 \mathrm{~nm}$ における吸光度), CD (色密度) は, 抽出腐植溶液全体の, $600 \mathrm{~nm}$ での吸光度である. これらの結果は, 大羽・本名（1984）の黒ボク土判定図 において K4 の領域にプロットされる（図 3).すなわ ち, 雁の巣黒ボク土は典型的な黒ボク土の腐植の特徴を 示し, フィールドで観察される産状とよく対応する.

\section{2. 鬼界アカホヤ火山灰（K-Ah）}

雁の巣黒ボク土中に多量に含まれる火山ガラスは, 一 般に淡褐色を帯びたバブルウォール型である。平均最大 
表 1 福岡平野の第四系層序表

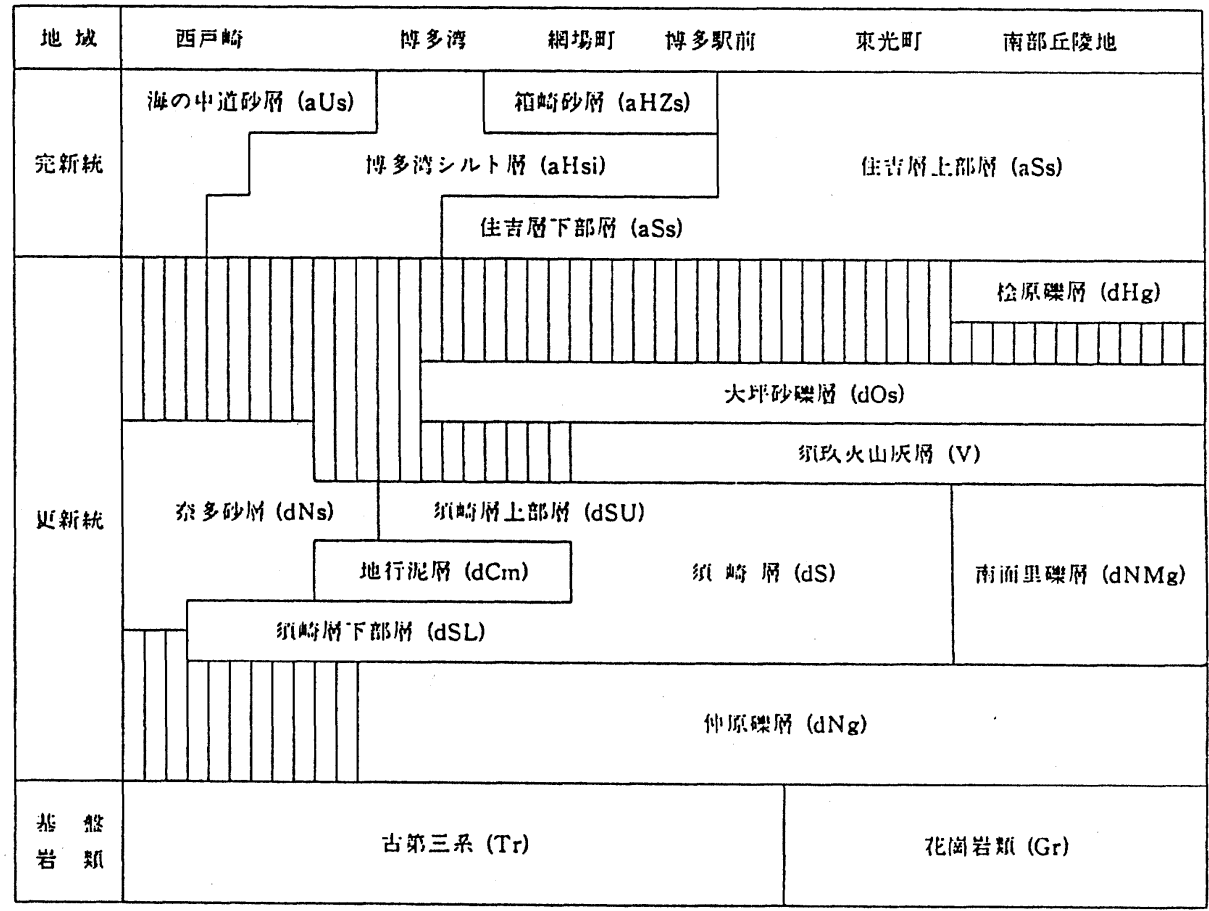

(下山, 1989)

\section{色調係数}

$(\triangle \operatorname{log~K}(\mathrm{NaOH}))$

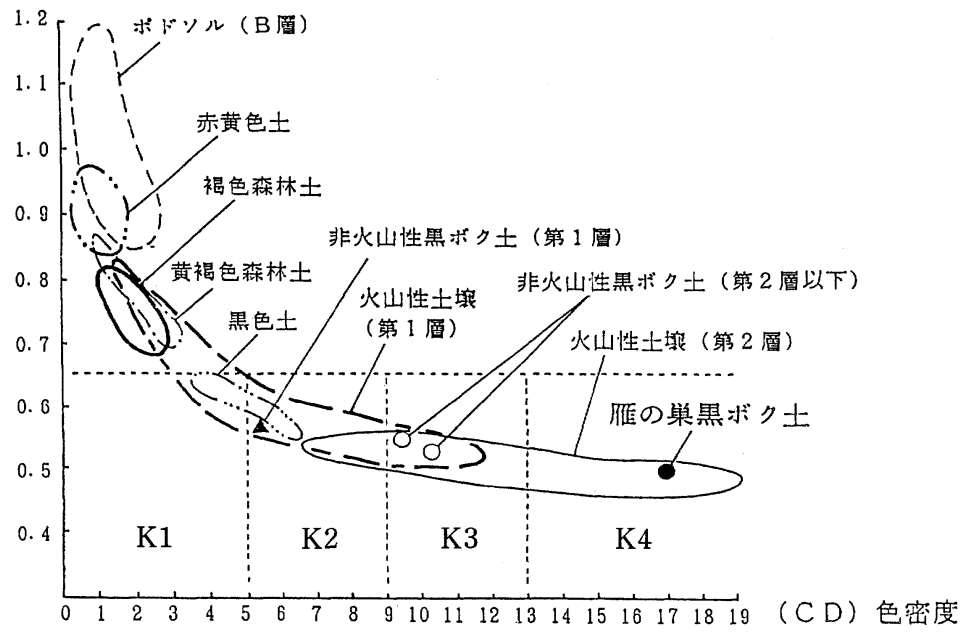

図 3 大羽・本名（1984）の黒ボク土判定図に基づく雁の巣黒ボク土の判定結果

$\Delta \log \mathrm{K}$ の值が 0.65 以下のものが黒ボク土の領域. K1 から K4 は 黑ボク土の区分. 雁の巣黑ボク土の位置は黒丸で示す. 


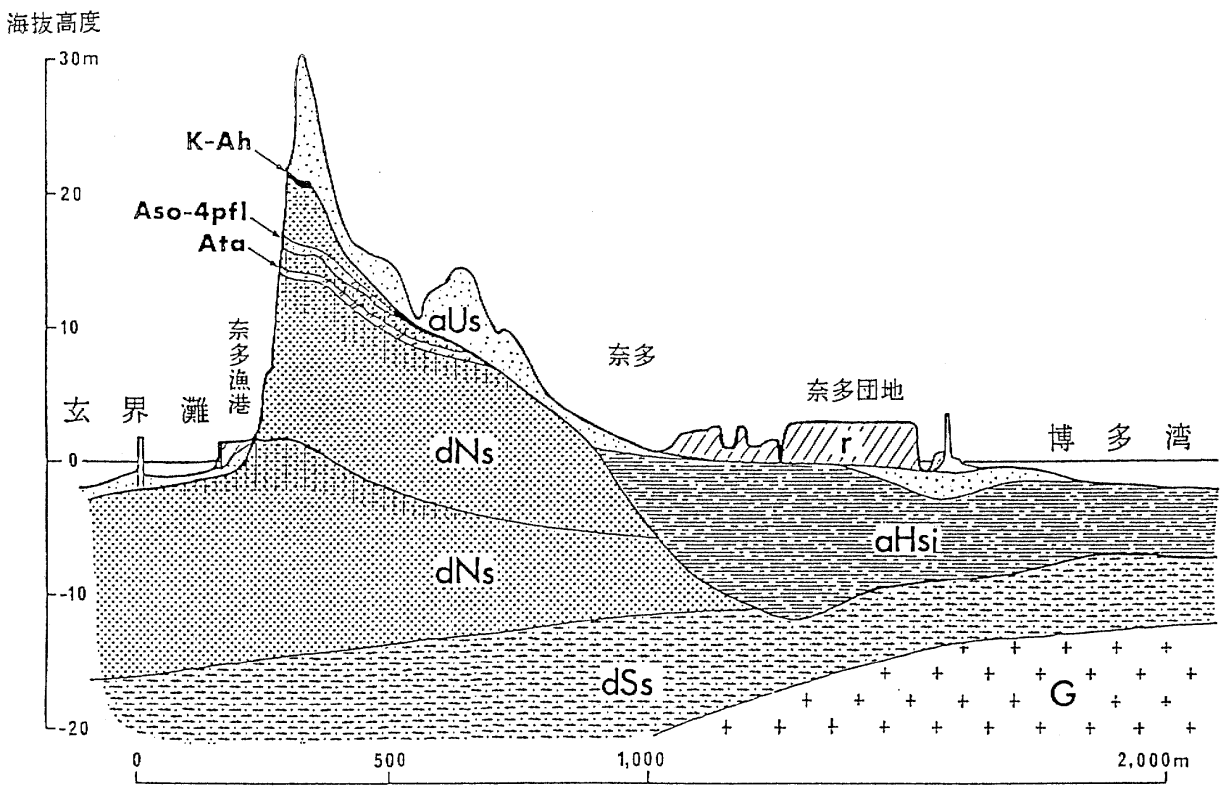

図 4 海の中道の模式断面図（福岡市東区奈多の玄界灘から博多湾にかけての断面） $\mathrm{r}$ : 人工埋積物 $\mathrm{aUs}$ : 海の中道砂層 $\mathrm{aHsi}$ : 博多湾シル卜層 $\mathrm{dNs}$ : 奈多砂層 $\mathrm{dSs}$ : 須 崎層 $\mathrm{G}$ : 基盤岩 (花崗岩類) $\mathrm{K}-\mathrm{Ah}$ : 鬼界アカホヤ火山灰 Aso-4 pf 1 : 阿蘇 4 火砕流 堆積物 Ata : 阿多火山灰

粒径は約 $1 \mathrm{~mm}$ ，測定された火山ガラスの屈折率の平均 レンジは 1.509〜1.513である. 火山ガラスの形状と屈 折率は，K-Ahのものとよく一致している（町田・新 井, $1983 \mathrm{a}, \mathrm{b})$. K-Ah は, 鬼界カルデラを起源とする 降下火山灰で，町田・新井 $(1978 ， 1983 b)$ は K-Ah の 年代として，6,000〜6,500y. B. P.あるいは 6,300 y. B. P.の值を与えている。 また，今回新たに測定された雁の 巣黒ボク土試料の ${ }^{14} \mathrm{C}$ 年代值は $6,470 \pm 100 \mathrm{y}$. B. P. （GaK-13344）で，この年代は K-Ah のものと比較的よ い一致をみる.

同様の埋没黒ボク土は，下山（1989）の住吉層下部層 中にも認められ，その厚さは住吉層中では $80 \mathrm{~cm}$ であ るが，粘土あるいは細砂と混在している．住吉層の埋没 黒ボク土は ${ }^{14} \mathrm{C}$ 年代測定值 $(6,260 \pm 110 \mathrm{y}$. B. P., $\mathrm{GaK}-13528)$ K-Ah を含有していることから, 雁の 巣黒ボク土とほぼ同時層であると判断される。この他, 完新世以前の堆積物や岩石の風化土壤の表面部にも，同 様の火山ガラスが混在しているが，火山ガラスの含有率 は埋没黒ボク土に比べてはるかに低い。系島郡志摩町, 福岡市天神，岡垣町榎坂付近では，いずれも埋没土中に 火山ガラスを多量に含み，これらは産状や火山ガラスの
屈折率から， $\mathrm{K}-\mathrm{Ah}$ に同定される，福岡県内では，埋没 土以外の土壌に含まれた $\mathrm{K}-\mathrm{Ah}$ は他の土壤物質と混 交・分散しており，明瞭なテフラ層を形成していない. 最近，こうした埋没黒ボク土を注目することにより，火 山ガラスを含む埋没土の存在が，にわかに福岡県内各地 から知られるようになった，産出層準も新砂丘砂層の直 下，平野部の完新統下部，丘陵地の更新統基盤の直上で あり，いずれも $\mathrm{K}-\mathrm{Ah} の$ 層準として矛盾がない。黑ボ ク土中に $\mathrm{K}-\mathrm{Ah}$ を多量に含むことは,このテフラの堆 積と黒ボク土の形成とは密接に関わりあっていることを 示唆するものである.これらの事実から，雁の巣黒ボク 土は $\mathrm{K}-\mathrm{Ah}$ を母材とする埋没黒ボク土であると判断さ れる。

\section{3. 阿蘇 4 火砕流 (Aso-4pfl)}

福岡平野に阿蘇カルデラ起源のテフラが散点的に分布 していることは, MATsumoto（1943）以来指摘されて きた。浦田（1962）は，春日市須玖付近に模式的に分布 するテフラを「須㺵火山死層」と呼んだ．須㺵火山在層 は福岡市博多区から那珂川町安德掞よび春日市春日原に いたるまとまった分布を示すほか，大野城市，福岡市南 区・早良区などに点在している。本層は，オレンジ色あ 
るいは暗赤褐色浮石質火山灰からなるが，しばしば暗灰 色を呈し，いわゆる“灰石”となっている部分もある. WATANABE（1978）は, 福岡地域の浮石質火山灰層を阿 蘇 4 火砕流堆積物（Aso-4pf）に同定した。

須玖火山灰層は, 須崎層の堆積面を覆うほか, 図 2 および図 4 に示すように, 奈多砂層 $\mathrm{B}$ 部層の表層部に 堆積している. 厚さは, 模式地付近の須玫火山灰層では 数 $\mathrm{m}$ ないし $10 \mathrm{~m}$, 奈多砂層中では $20 \mathrm{~cm}$ 程度であ る. 奈多砂層中に介在するテフラは, 浮石質火山灰より なり，一般に火山ガラスの大部分は粘土化して消失し， 全体としてオレンジ色あるいは暗赤褐色を呈している. この火山灰は, 粗粒なバブルウォール型火山ガラス・斜 長石・斜方輝石 - 単斜輝石・褐色角閃石 - 磁鉄鉱からな り, 火山ガラス以外では特に褐色角閃石と斜方輝石に富 む組成を持っ. 火山ガラス, 斜方輝石 $(\gamma)$, 角閃石 $\left(\mathrm{n}_{2}\right)$ の屈折率のレンジは, それぞれ $1.508 \sim 1.511$, $1.699 \sim 1.701,1.686 \sim 1.689$ であ. 本層の下部に は，外来岩片や炭化木片を巻き込んでおり，火山灰の組 織・組成・鉱物の粒度や屈折率から, Aso-4pflに同定 される. 町田・新井 (1983b, 1985) は, Aso-4pfl の噴 出年代として, 約 70,000 y. B. P.の值を与えている. 安 德の台地をつくる火山灰層は, 暗灰色で火山ガラスに富 み，他の須㺵火山灰層とは見かけ上異なる。また，一般 に須㺵火山灰層の下部は, 含水率, 粘土化の程度がとも に高く，ハロイサイトに富んで㧍り，乳白色または灰白 色を呈する.このため, 須玫火山灰層は上部がオレンジ 色または暗赤褐色，下部が乳白色となり，その境界は不 明瞭である．鉱物組成には変化がないことから，この上 半部を鳥栖ローム層, 下半部を八女粘土層という 2 種 類の火山兏層（Aso-4pflのサブユニット）に分けた り，安徳の火山灰層を区別する（矢ヶ部・向山, 1979） のは適切ではなく，むしろこれらは 1 種類のテフラ層 の粘土化程度の差と思われる（下山ほか，1984）。

\section{4. 阿多火山灰 (Ata)}

奈多漁港の露頭（図 2, Loc. 1, 2) では, 奈多砂層 中のAso-4pfl の下位約 $3.5 \mathrm{~m}$ の C 部層中に明瞭なテフ ラ層が認められる. 岡垣町榎坂 (図 2, Loc. 3) では, 古砂丘砂層中の Aso-4pfl の下位約 $2.5 \mathrm{~m}$ に同様のテフ ラ層が位置している。これらはオレンジ色の風化火山灰 層で, 厚さは Loc. 1, 2 で約 $5 \mathrm{~cm}$, Loc. 3 で約 $50 \mathrm{~cm}$ である．本層は本来火山ガラスを主体としていたと思わ れるが, Loc. 1〜2 の大部分と Loc. 3 の露頭では風化が 著しく, そのほとんどが消失し, 粘土化している. しか L, Loc. 2 の露頭では, 部分的に比較的保存の良好な 火山灰があり, 火山ガラスのほか, 斜方輝石, 単斜輝
石，角閃石の結晶を含んでいることが確認された，火山 ガラスはバブルウォール型・平均最大粒径 $0.4 \mathrm{~mm}$ 程 度で, その屈折率のレンジは 1.504 1.510, 中央值の レンジは 1.507〜1.510である. また, 斜方輝石は微細 な自形をなし, 多量に含まれることから, 本源物質とみ なすことができる．斜方輝石の屈折率 $(\gamma)$ のレンジは $1.705 \sim 1.710$ である.これらの岩石記載的特徵と Aso-4pfl の下位であるという層序学的事実からみて, この火山灰層は町田・新井 $(1983 \mathrm{a})$ による Ata である 可能性が最も高い. Ata は, 鹿児島県阿多カルデラを起 源とする降下火山灰で, 町田・新井 (1983 b), FURUTA et al. (1986) は, Ataの年代として約 90,000 y. B. P. を与えている。なお，図 2 の柱状図（Loc. 2）に示した ように, 海水準近くの奈多砂層 $\mathrm{D}$ 部層の直上の埋もれ 木層から得られた埋もれ木試料の ${ }^{14} \mathrm{C}$ 年代值は 23,840 \pm 880 y. B. P. (Gak-13309) である.この年代值は埋も れ木の産出層準が Aso-4pfl および Ata の下であるとい う事実や, 福岡での層序学的解勫と矛盾する. この年代 值が ${ }^{14} \mathrm{C}$ 年代測定の技術的限界に近いことに加え, 測定 試料は一見新鮮にみえる樹木片であるものの, 上下が透 水性のよい砂丘砂層であることからみて, 現代炭素を含 む天水との交換を行った可能性が強く, 埋もれ木の ${ }^{14} \mathrm{C}$ 年代值は産出層準の年代を示していないと判断され る.

成瀬・井上（1982）で報告された KTは, 自形結晶 がないほど風化が著しいこと, 斜方輝石の屈折率のレン ジが似ていること, Aso-4pflの下位の層準であること 等の点で今回 Ata に同定された火山灰の特徴と一致し ている.このため, KT は産出の層序学的状況などから みて，今回確認された Ata に相当すると判断される.

\section{III. おわりに}

噴出源を含む同じ九州でありながら, 給源火山群の北 西に位置する福岡平野周辺地域では, 従来 Aso-4pfl 以 外の広域テフラについてそれほど注意が払われてこなか った.これには, 前記のような特徵的な火山灰の産状の ほか, この地域の考古学的な研究が弥生時代から古代に 重点が置かれてきたこととも無関係ではないと思われ る.しかし, K-Ah と Ata のテフラ層準がこの地域の 露頭で確認され，これらが普遍的に分布することを本論 文で明らかにすることができた。これによって福岡平野 周辺地域でも，北部九州の第四系の編年・対比に関する 有力な鍵層を得たことになる．また，今回明瞭なテフラ 層の確認までは至らなかった姶良 Tn 火山死（AT）に ついても, 今後の埋蔵文化財の発掘調査等において, 埋 
没土層断面中に発見される可能性が高くなった。これら の結果は, 日本海沿岸の古砂丘の対比にも利用可能と思 われる。

\section{引用 文 献}

藤井厚志（1986）岡垣町の地質。岡坦町自然環境調查報告 書, 44p., 岡坦町教育委員会.

Furuta, T., FujIOKA, K. and ARAI, F. (1986) Widespread submarine tephras around Japan - Peterographic and chemical properties. Mar. Geol., 72, p. 125-142.

町田 洋・新井房夫（1978）南九州鬼界カルデラから噴出 した広域テフラーアカホヤ火山灰. 第四紀研究, 17 p. 143-163.

町田 洋・新井房夫 (1983a) 鬼界カルデラ起源の新広域テ フラと九州における更新世後期大火砕流の噴出年代. 火 山, 第 2 集, 28, p. 206.

町田 洋・新井房夫（1983b）広域テフラと考古学．第四紀 研究, 22, p. 133-148.

町田 洋・新井房夫（1985）阿蘇 4 火山灰一一分布の広域 性と後期更新世指標層としての意義——. 火山，第 2 集, 30, p. 49-70.
Matsumoto, T. (1943) The four gigantic caldera volcanoes of Kyushu. Japan Jour. Geol. Geogr., 19, Special no., p. $1-57$.

成瀬敏郎・井上克弘（1982）北九州および与那国島のレス 一後期更新世血成塵の意義. 地学雑誌, 91, p. 164-180.

大羽 裕・本名俊正（1984）黑ボク土判定のための腐植の 分析法. 土肥誌, 55, p. 55-61.

下山正一（1989）福岡平野における緡文海進の規模と第四 紀層. 九大理研報 (地質), 16, p. 37-58.

下山正一・亀山徳彦・宮田雄一郎・田代雄二（1984）福岡 糸島平野の第四系。北九大文紀要 (B), 17, p. 39-58.

浦田英夫（1962）福岡市付近の平坦面の地史学的研究. 九 大教養地学研報, no. 8, p. 1-45.

Watanabe, K. (1978) Studies on the Aso pyroclastic flow deposits in the region to the west of Aso caldera, southwest Japan, I : Geology. Mem. Fac. Educ. Kumamoto Univ., no. 27, Nat. Sci., p. 97-120.

矢ヶ部秀美・向山 広 (1979) 福岡平野および筑紫平野の 周辺に分布するテフラ層とその風化について. 九大工学 報，52，p. 287-293. 